\title{
Evaluasi dan Retrofit Struktur Gedung Beton Bertulang Akibat Kebakaran
}

\author{
Nurul Hidayati ${ }^{\mathrm{a}^{*}}$, Henricus Priyosulistyo $^{\mathrm{b}}$, Andreas Triwiyono $^{\mathrm{b}}$ \\ ${ }^{a}$ Program Pascasarjana, Departemen Teknik Sipil dan Lingkungan, Universitas Gadjah Mada, Yogyakarta, 565223, Indonesia \\ ${ }^{\mathrm{b}}$ Departemen Teknik Sipil dan Lingkungan, Universitas Gadjah Mada, Yogyakarta, 565223, Indonesia
}

\begin{abstract}
Keywords:

Evaluation

Feasibility,

Structural strengthening,

CFRP

Steel bracing.

Several studies have been carried out related to the impact of fire on the strength of reinforced concrete material. It shows that there is a decrease in strength and a decrease in structural stiffness. The degree of damage is dependent on the temperature and duration of the fire. To ensure accessibility, the building needs to be evaluated whether the building can be refunctioned immediately. The results of site investigation are evaluated to determine the structure retrofit and reinforcement methods and cost-effectiveness compared to the cost of a new building. The office building structure under review is analytically evaluated based on SNI 1726:2019 and SNI 1727:2018. The results showed that 31\% of columns and 32\% of beams need to be strengthened. In addition, steel bracing and CFRP wrapping on the structural elements were applied. The cost of retrofitting required Rp2.998.488.781,07, which is lower than the cost of the new building structure, which costs Rp4.950.087.016,34.
\end{abstract}

Kata kunci:

Evaluasi

Fisibilitas

perkuatan struktur

CFRP

Bracing baja

\begin{abstract}
ABSTRAK
Beberapa penelitian yang telah dilakukan terkait dampak kebakaran terhadap kekuatan material beton bertulang, memperlihatkan bahwa terdapat penurunan kekuatan dan kapasitas struktur. Tingkat penurunan tergantung antara lain pada suhu dan durasi kebakaran. Untuk meyakinkan tingkat fisibilitas, gedung tersebut perlu dievaluasi kemungkinan dapat atau tidaknya gedung itu difungsikan kembali. Hasil evaluasi tersebut dijadikan pertimbangan dalam menentukan metode perbaikan dan perkuatan yang efektif untuk kemudian dibandingkan dengan biaya pembangunan gedung baru. Struktur gedung kantor PLN Unit Cabang Distribusi Jakarta Raya ini akan dievaluasi dengan cara analitis berdasarkan SNI 1726:2019 dan SNI 1727:2018. Terdapat total $31 \%$ kolom dan $32 \%$ balok yang perlu diperkuat. Metode perkuatan yang digunakan adalah penambahan bracing baja dan CFRP. Material CFRP tersebut dililitkan pada elemen struktur. Biaya perkuatan yang diperlukan adalah Rp2.998.488.781,07, lebih rendah dibandingkan nilai struktur gedung, yaitu Rp4.950.087.016,34.
\end{abstract}

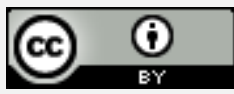

This is an open access article under the CC-BY license.

\section{Pendahuluan}

Pengaruh pemanasan pada beton pada temperatur $200^{\circ} \mathrm{C}$ dapat memberi keuntungan pada beton, karena akan menyebabkan penguapan air dan penetrasi kedalam rongga-rongga beton, sehingga dapat meningkatkan sifat lekatan antar partikel-partikel C-S-H (kalsium silikat). Kuat-tekan beton benda uji silinder maupun kuat lentur benda uji yang dipanaskan dalam tungku pada temperatur $200^{\circ} \mathrm{C}$ meningkat sekitar $10-15 \%$ dibandingkan dengan beton normal tanpa dipanaskan [1]. Perubahan warna mulai terjadi pada saat suhu mencapai $300^{\circ} \mathrm{C}$. Beton yang terkena suhu antara $300-600{ }^{\circ} \mathrm{C}$ akan berubah warna menjadi abu-abu normal hingga warna merah muda, mulai berubah menjadi warna putih keabu-abuan pada suhu 600$900^{\circ} \mathrm{C}$, dan warna abu-abu pucat pada saat suhu mencapai 900-1000 ${ }^{\circ} \mathrm{C}[2]$.

Tegangan leleh baja tulangan secara umum meningkat $2 \%$ setelah mengalami pembakaran, tegangan tekan beton menurun $25-35 \%$ pada beton normal, modulus elastisitas pelat beton normal berkurang $73 \%$ setelah dibakar, kekuatan pelat beton mutu normal dan mutu tinggi menunjukkan penurunan kemam-puan sebesar 11,6\%

*Corresponding author.

E-mail: nurulhidayati2018@mail.ugm.ac.id 
setelah pembakaran, kekakuan pelat beton setelah dibakar juga menurun sebesar 76\% [3].

Beton terbakar mengalami perubahan pada mikrostrukturnya. Menurut penelitian [2] yang memperhatikan sifat beton terbakar dengan meninjau sifat pasta semen, rongga dan retak, serta jalur retak yang ditemukan pada sampel beton terbakar. Perubahan fase, sifat kimiawi, dan terjadinya evaporasi serta berkurangnya lekatan antara mikrostruktur beton akan mempengaruhi penurunan mutu beton.

Sifat-sifat beton bertulang yang mengalami degradasi akibat kebakaran adalah kuat tekan, modulus elastisitas, mengalami retak hingga spalling pada beton, sedangkan pada baja tulangan terjadi penurunan kuat leleh, daktilitas, dan kuat tarik baja, serta berkurangnya lekatan antara beton dan tulangan [4].

Studi kasus evaluasi dan retrofit pada penelitian ini adalah Gedung PLN Unit Cabang Distribusi Jakarta Raya, salah satu kantor unit cabang distribusi. Struktur gedung tersebut terbuat dari material beton bertulang ini terdiri dari 3 lantai tinggi tiap lantai 4 meter, memiliki dimensi panjang total 50 meter dan lebar total 32 meter. Gedung tersebut mengalami kebakaran dengan durasi 3 jam. Penyebab kebakaran adalah terjadinya arus pendek listrik pada salah satu bagian gedung.

Beberapa penelitian yang telah dilakukan terkait dampak kebakaran terhadap kekuatan material beton bertulang, memperlihatkan bahwa terdapat penurunan kekuatan dan penurunan kapasitas struktur. Penelitian ini bertujuan untuk melakukan evaluasi kekuatan bangunan atas (upper structure) gedung PLN Unit Cabang Distribusi Jakarta Raya. Evaluasi dilakukan dengan cara analitis, melalui tahap analisis struktur yang disesuaikan dengan kondisi eksisting dana berdasarkan standar terbaru yang berlaku agar gedung dapat difungsikan kembali.

Hasil evaluasi yang telah diperoleh digunakan untuk meninjau perlunya struktur untuk diperkuat atau membangun bangunan gedung yang baru dengan membandingkan biaya pelaksanaan pekerjaan dan aspek ketersediaan lahan.

Konsep dasar dari perkuatan yaitu meningkatkan kekuatan lateral struktur, meningkatkan daktilitas struktur, dan meningkatkan kekuatan dan daktilitas struktur. Metode perkuatan dapat diitinjau dari dua aspek, yaitu perkuatan secara global dan lokal. Perkuatan secara global adalah perkuatan yang diberikan kepada gedung ketika tidak memenuhi beberapa persyaratan struktural seperti defleksi/torsi secara struktural, mode shape, $\mathrm{P}-\Delta$, periode gedung, story drift. Sedangkan perkuatan lokal diberikan ketika elemen struktur sudah tidak mampu menahan beban yang bekerja pada struktur bangunan. Jenis perkuatan global yang umum dilakukan, yaitu pemberian bracing baja dan dinding geser. Sedangkan jenis perkuatan lokal yang dapat diterapkan pada elemen gedung adalah steel jacketing, concrete jacketing, atau CFRP wrapping.

\section{Metode}

Metode evaluasi yang digunakan pada penelitian ini dibagi menjadi beberapa tahap, yaitu observasi lapangan, pengumpulan data, analisis data menggunakan statistik, analisis struktur, pemilihan metode perkuatan, dan perhitungan Rencana Anggaran Biaya (RAB).

Data mutu material untuk elemen kolom, balok, dan pelat yang digunakan dalam analisis berbeda-beda. Data tersebut diolah dengan analisis statistika dan dijadikan sebagai data untuk analisis menggunakan program SAP2000. Pemodelan dilakukan berdasarkan gambar denah yang dilengkapi dengan data pengukuran lapangan serta nilai mutu material oleh tim Laboratorium Bahan Fakultas Teknik Sipil Universitas Indonesia. Pemodelan dibuat sesuai hasil pengukuran lapangan dengan data gempa berdasar pada SNI 1726:2012 dan SNI 1727:2018 [5], [6].

Proses evaluasi pada penelitian ini menyesuaikan dengan standar yang sedang berlaku di Indonesia, yaitu SNI 1726:2019 dan SNI 1727:2018 [5]-[7] untuk prosedur analisis linier statik. Sedangkan prosedur analisis nonlinier statik (pushover) menggunakan standar ASCE 41-17 dan ATC40 [8].

Respons spektrum yang digunakan pada peraturan ini adalah respons spektrum gempa yang kemungkinan terjadinya $10 \%$ dalam kurun waktu 50 tahun, yaitu gempa dengan periode ulang 500 tahun. Perubahan tinjauan pedoman analisis gempa tersebut menyebabkan struktur yang telah direncanakan dengan aman sesuai dengan peraturan terdahulu bisa menjadi tidak aman dalam tinjauan pedoman yang berlaku saat ini. Ragam getar alami untuk struktur harus ditentukan melalui analisis yang menyertakan jumlah ragam yang cukup untuk mendapatkan partisipasi massa ragam terkombinasi sebesar paling sedikit $90 \%$ dari massa aktual. Simpangan antar tingkat desain $(D)$ tidak boleh melebihi simpangan antar tingkat izin $\left(D_{a}\right)$ seperti didapatkan pada Tabel 1. 
Tabel 1. Simpangan antar tingkat izin $\left(D_{a}\right)$

\begin{tabular}{cccc}
\hline Struktur & \multicolumn{3}{c}{ Kategori risiko } \\
& I atau II & III & IV \\
\hline $\begin{array}{c}\text { Struktur, selain dari struktur } \\
\text { dinding geser batu bata, } 4 \\
\text { tingkat atau kurang dengan } \\
\text { dinding interior, partisim } \\
\text { langit-langit dan sistem } \\
\text { dinding interior yang telah } \\
\quad \text { didesain untuk }\end{array}$ & $0,025 h_{s x}$ & $0,020 h_{s x}$ & $0,015 h_{s x}$ \\
$\begin{array}{c}\text { mengakomodasi simpangan } \\
\text { antar lantai tingkat }\end{array}$ & & & \\
$\begin{array}{c}\text { Struktur dinding geser } \\
\text { kantilever batu bata }\end{array}$ & $0,010 h_{s x}$ & $0,010 h_{s x}$ & $0,010 h_{s x}$ \\
$\begin{array}{c}\text { Struktur dinding geser batu } \\
\text { bata lainnya }\end{array}$ & $0,007 h_{s x}$ & $0,007 h_{s x}$ & $0,007 h_{s x}$ \\
Semua struktur lainnya & $0,020 h_{s x}$ & $0,015 h_{s x}$ & $0,010 h_{s x}$ \\
\hline
\end{tabular}

Ketika prosedur statik nonlinier digunakan untuk analisis seismik bangunan gedung maka masing-masing elemen gedung akan menerima beban lateral yang meningkat secara monoton yang mewakili gaya inersia dalam gempa bumi sampai target displacement terlampaui [8]. Hubungan antara gaya geser dan displacement lateral dari noda kontrol ditetapkan pada Pasal 7.4.3.2 yang berkisar antara 0 sampai $150 \%$ dari target displacement.

Struktur gedung dalam kasus ini dimodelisasi sebagai portal ruang 3-D dengan 9 derajat kebebasan (Degree of Freedom) pada tiap nodal. Analisis yang dilakukan adalah analisis elastis dimana kekakuan EI yang digunakan harus mewakili kekakuan komponen struktur sesaat sebelum kegagalan. Balok dan kolom dimodelkan menggunakan material beton bertulang dan sebagai batang frame. Hubungan kolom dan balok diasumsikan bersifat kaku dan dapat memikul beban momen. Sedangkan pelat lantai diidealisasi sebagai diafragma kaku disetiap lantainya dan akan bergerak bersama-sama ketika terkena beban gempa. Pemodelan elemen kolom, balok, dan pelat lantai ditampilkan pada Gambar 1 .

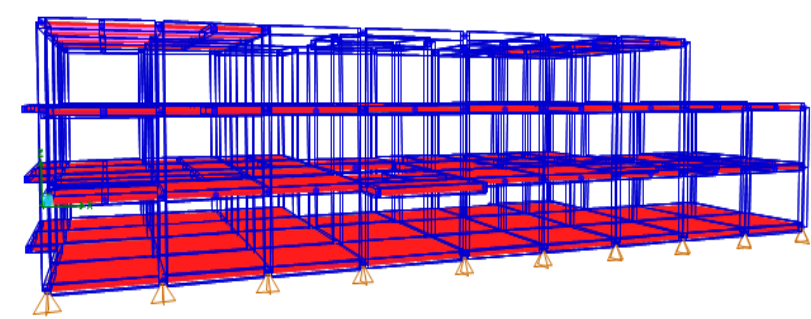

Gambar 1. Pemodelan struktur

\section{Hasil dan Diskusi}

Mutu material yang digunakan dalam analisis struktur diperoleh dari hasil uji lapangan dan laboratorium yang kemudian dianalisis secara statistik untuk menghilangkan data outlier. Kuat tekan beton masih perlu dikalikan dengan faktor koreksi $\left(C_{3}\right)$ jika diameter bor inti tidak sama dengan diameter silinder standar, yaitu 6 inchi [9].

Sehingga diperoleh mutu beton yang akan digunakan pada analisis struktur yang ditampilkan pada Tabel 2 dan mutu baja ditampilkan pada Tabel 3. Data mutu material untuk perencanaan pada tabel tersebut menggunakan data kuat tekan rerata dari data yang memiliki nilai $\mathrm{CoV}$ dibawah $20 \%$. f' ${ }_{c}$ merupakan data kuat tekan beton dari hasil uji lapangan, sedangkan $\mathrm{f}^{\prime}{ }_{\mathrm{cc}}$ merupakan data kuat tekan beton setelah diberi perkuatan [10].

Tabel 2. Mutu beton elemen struktur untuk perencanaan

\begin{tabular}{clccc}
\hline No. & & Elemen & $\mathrm{f}^{\prime} \mathrm{c}(\mathrm{MPa})$ & $\mathrm{f}^{\prime} \mathrm{cc}(\mathrm{MPa})$ \\
\hline 1. & Kolom Lt. 1 & 12,46 & 29,78 \\
2. & Kolom Lt. 2 & 17,62 & 42,11 \\
3. & Kolom Lt. 3 & 14,32 & 34,23 \\
4. & Balok Lt. 1 & 14,28 & 34,13 \\
5. & Balok Lt. 2 & 14,68 & 35,08 \\
6. & Balok Lt. 3 & 12,43 & 29,70 \\
7. & Pelat & 18,13 & \\
\hline
\end{tabular}

$\mathrm{f}_{\mathrm{c}}$ : tegangan tekan beton eksisting; $\mathrm{f}_{\mathrm{cc}}$ : tegangan tekan beton setelah dilapis CFRP

Tabel 3. Mutu baja elemen struktur untuk perencanaan

\begin{tabular}{clcc}
\hline No. & \multicolumn{1}{c}{ Elemen } & $f_{y}{ }^{*}(\mathrm{MPa})$ & $f_{y}(\mathrm{MPa})$ \\
\hline 1. & Kolom Lt. 1 & 396 & \\
2. & Kolom Lt. 2 & 436 & 421 \\
3. & Kolom Lt. 3 & 430 & \\
4. & Balok Lt. 1 & 405 & \\
5. & Balok Lt. 2 & 451 & 423 \\
6. & Balok Lt. 3 & 415 & \\
7. & Pelat Lt. 2 & 200 & \\
8. & Pelat Lt. 3 & 198 & \\
\hline
\end{tabular}

$\mathrm{f}_{\mathrm{y}}{ }^{*} \overline{\text { : mutu baja hasil pengukuran lapangan; } f_{y}: \text { mutu baja perencanaan }}$ 
Partisipasi massa yang dihasilkan pada pemodelan sudah memenuhi syarat pada mode ke 20, yaitu sebesar $95,58 \%$ pada arah X dan pada mode ke 19 sebesar $95,76 \%$ pada arah Y.

Nilai gaya geser dasar pada struktur ini diperoleh bahwa $\mathrm{V}_{\text {dinamik }}>0,8 \times \mathrm{V}_{\text {statik}}$, maka skala gaya pada analisa respon spektrum tidak perlu diperbesar atau menggunakan angka faktor pengali 1. Sehingga skala gempa yang digunakan pada analisa respon spektrum pada pemodelan ini adalah:

$$
\text { Arah } \mathrm{X}=9,81 / R=9,81 / 5=1,962
$$$$
\text { Arah } \mathrm{Y}=9,81 / R=9,81 / 5=1,962
$$

Hasil perhitungan simpangan antar lantai akibat gempa arah X dan gempa arah Y dibandingkan dengan syarat ijin dapat dilihat pada Tabel 4 dan Tabel 5.

Peraturan menyebutkan bahwa struktur disyaratkan boleh mengalami rotasi hanya sekali dalam 3 mode getar pertama. Sedangkan dalam pemodelan ini, struktur mengalami rotasi pada mode pertama dan ketiga. Struktur perlu diberi perkuatan global seperti diberi dinding geser atau bracing baja untuk menghilangkan rotasi yang terjadi. Mode ragam getar struktur ditampilkan pada Tabel 6.

Tabel 4. Simpangan antar lantai akibat gempa arah X (m)

\begin{tabular}{ccccc}
\hline Lantai & $\begin{array}{c}\text { Tinggi } \\
\text { lantai }(\mathrm{mm})\end{array}$ & Drift ratio & $\Delta_{a}(\mathrm{~mm})$ & Cek \\
\hline Lt 3 & 4000 & $3,86 \%$ & $2,5 \%$ & Not Ok \\
Lt 2 & 4000 & $2,16 \%$ & $2,5 \%$ & Ok \\
Lt 1 & 4000 & $0,00 \%$ & $2,5 \%$ & Ok \\
\hline
\end{tabular}

Tabel 5. Simpangan antar lantai akibat gempa arah Y (m)

\begin{tabular}{ccccc}
\hline Lantai & $\begin{array}{c}\text { Tinggi Lantai } \\
(\mathrm{mm})\end{array}$ & $\begin{array}{c}\text { Drift } \\
\text { ratio }\end{array}$ & $\begin{array}{c}\Delta_{a} \\
(\mathrm{~mm})\end{array}$ & Cek \\
\hline Lt 3 & 4000 & $1,26 \%$ & $2,5 \%$ & Ok \\
Lt 2 & 4000 & $1,13 \%$ & $2,5 \%$ & Ok \\
Lt 1 & 4000 & $1,39 \%$ & $2,5 \%$ & Ok \\
\hline
\end{tabular}

Tabel 6. Mode ragam getar struktur

\begin{tabular}{cc}
\hline Mode ragam getar & Periode (s) \\
\hline I (rotasi) & 1,081 \\
II (translasi) & 1,047 \\
III (rotasi) & 0,994 \\
\hline
\end{tabular}

Berdasarkan data yang telah dimasukkan dalam pemodelan pada penelitian ini, terdapat beberapa elemen struktur yang overstress dan memiliki column P-M-M interaction ratios melebihi ambang batas $(0,95)$ yang ditampilkan pada Gambar 2 sampai Gambar 4. Persentase elemen kolom dan balok yang perlu diperkuat ditampilkan pada Tabel 7 .

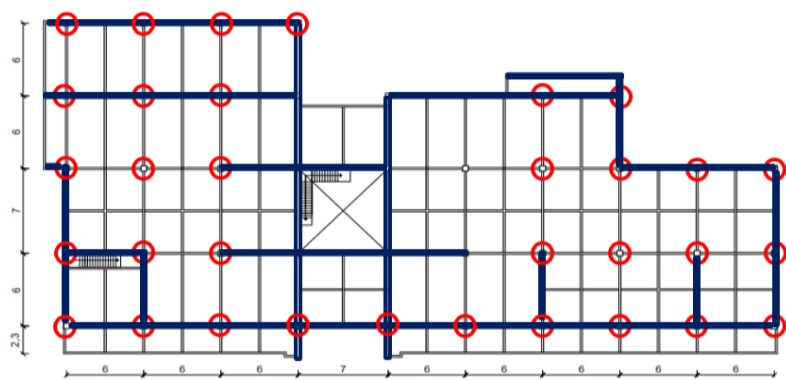

Gambar 2. Denah elemen overstress di lantai 1

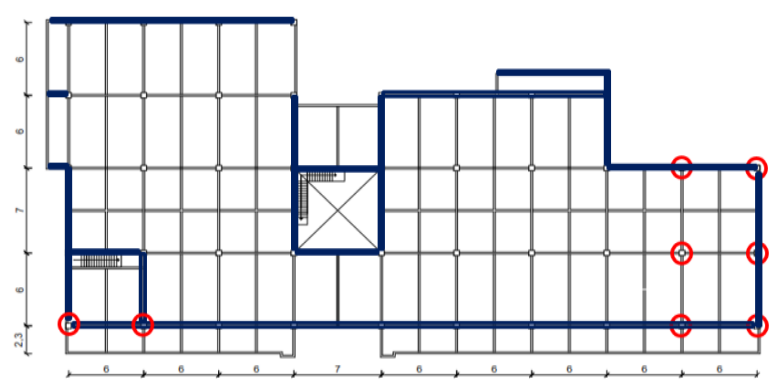

Gambar 3. Denah elemen overstress di lantai 2

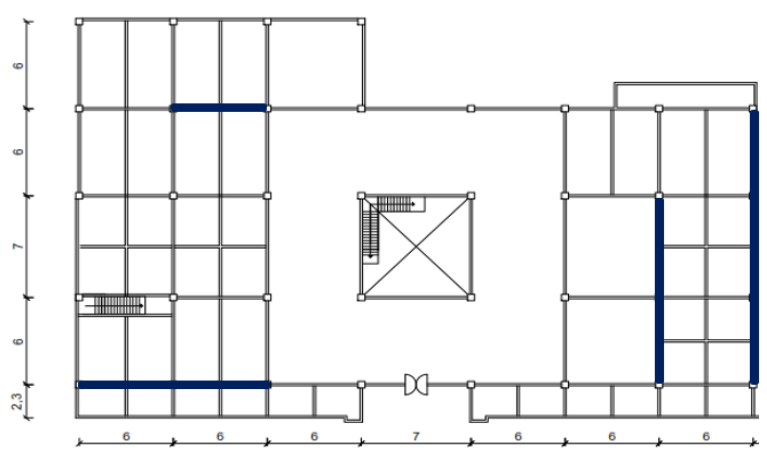

Gambar 4. Denah elemen overstress di lantai 3

Tabel 7. Persentase elemen yang perlu diperkuat

\begin{tabular}{ccc}
\hline Lantai & Kolom & Balok \\
\hline Lantai 1 & $79 \%$ & $60 \%$ \\
Lantai 2 & $17 \%$ & $39 \%$ \\
Lantai 3 & $0 \%$ & $18 \%$ \\
\hline
\end{tabular}

Berdasarkan hasil analisis yang diperoleh, struktur gedung yang ditinjau memerlukan dua jenis perkuatan, yaitu perkuatan global (struktur) dan perkuatan lokal (elemen struktur). Perkuatan global yang digunakan dalam kasus ini adalah bracing baja karena metode perkuatan ini tidak memberikan bobot berat yang signifikan terhadap struktur jika dibandingkan dengan melakukan perkuatan dengan dinding geser. Perkuatan lokal yang diberikan pada elemen struktur adalah CFRP dengan metode wrapping yang dapat meningkatkan kekuatan elemen struktur karena berdasarkan hasil uji mutu bahan yang telah 
dilakukan mutu material struktur masih dibawah standar sehingga perlu ditingkatkan.

Drift ratio lantai 3 untuk arah X, struktur tidak memenuhi persyaratan. Selain itu, mode getar struktur pada mode pertama adalah rotasi sehingga kekakuan struktur perlu ditingkatkan. Salah satu cara untuk meningkatkan kekakuan struktur adalah dengan memasang pengaku (bracing) untuk bangunan. Pada penelitian ini, sistem pengaku struktur yang akan diberikan adalah penambahan bracing baja pada sisi terluar bangunan. Dimensi bracing baja yang akan diberikan adalah IWF 200x100x8x5,5 dengan model perkuatan bracing baja ditampilkan pada Gambar 5. Lokasi penempatan bracing baja pada struktur ditampilkan pada Gambar 6 sampai dengan Gambar 8.

Berdasarkan dimensi yang dimodelkan dalam SAP2000, diperoleh bahwa struktur gedung setelah diberi perkuatan mengalami perubahan mode shape yang ditampilkan pada Tabel 8. Drift ratio struktur gedung juga turun dan memenuhi syarat seperti yang ditampilkan pada Tabel 9.

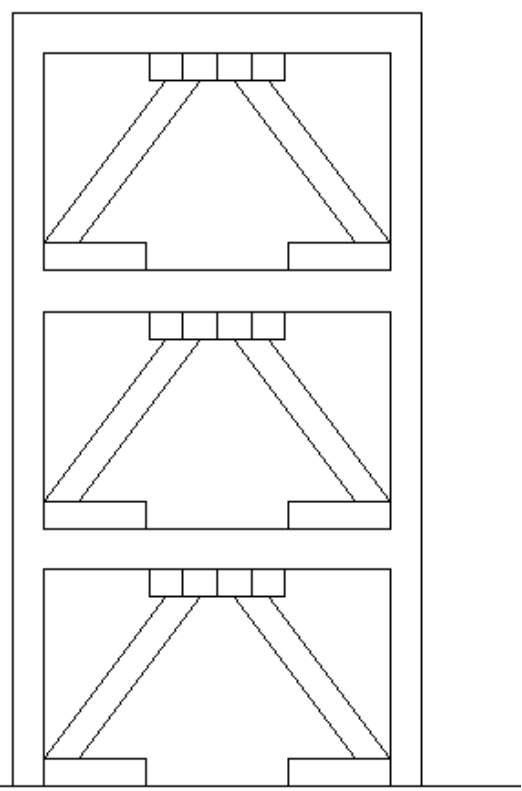

Gambar 5. Model perkuatan bracing baja

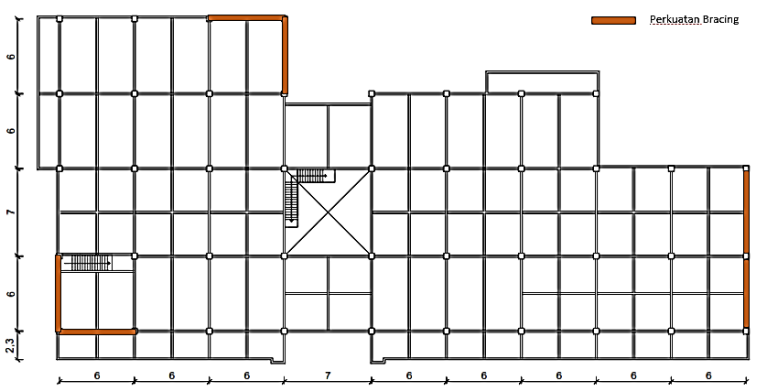

Gambar 6. Letak bracing baja di lantai 1

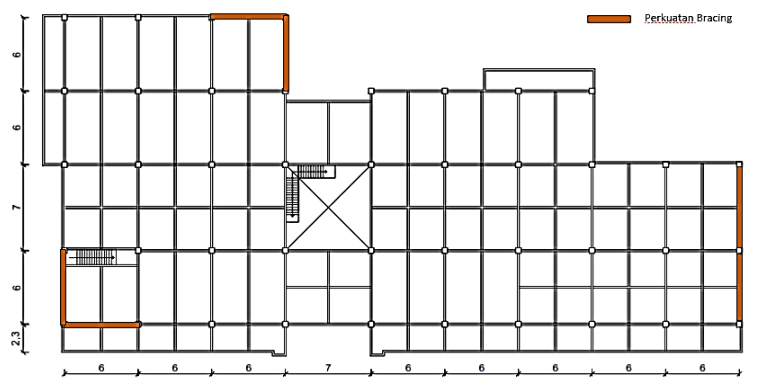

Gambar 7. Letak bracing baja di lantai 2

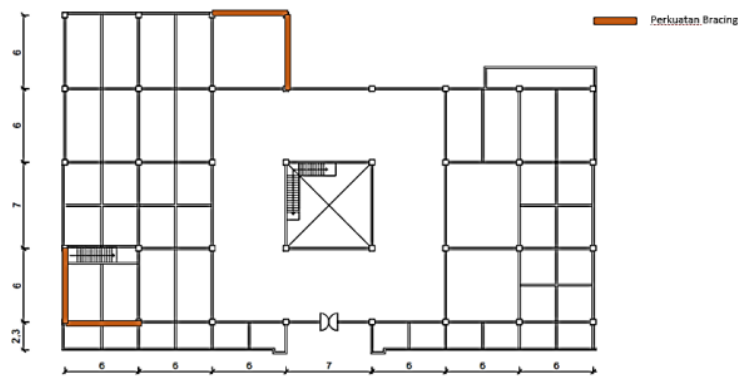

Gambar 8. Letak bracing baja di lantai 3

Tabel 8. Perbedaan mode shape sebelum dan sesudah diberi perkuatan

\begin{tabular}{cccc}
\hline \multicolumn{2}{c}{ Sebelum diperkuat } & \multicolumn{2}{c}{ Setelah diperkuat } \\
\hline $\begin{array}{c}\text { Mode ragam } \\
\text { getar }\end{array}$ & $\begin{array}{c}\text { Periode } \\
(\mathrm{s})\end{array}$ & $\begin{array}{c}\text { Mode ragam } \\
\text { getar }\end{array}$ & $\begin{array}{c}\text { Periode } \\
(\mathrm{s})\end{array}$ \\
\hline I (rotasi) & 1,081 & I (translasi) & 0,683 \\
II (translasi) & 1,047 & II (translasi) & 0,596 \\
III (rotasi) & 0,994 & III (rotasi) & 0,380 \\
\hline
\end{tabular}

Tabel 9. Perubahan drift ratio sebelum dan sesudah diberi perkuatan (Arah X)

\begin{tabular}{ccccc}
\hline Lantai & $\begin{array}{c}\text { Drift ratio } \\
\text { sebelum } \\
\text { diperkuat }\end{array}$ & $\begin{array}{c}\text { Drift } \\
\text { ratio } \\
\text { setelah } \\
\text { diperkua } \\
\mathrm{t}\end{array}$ & $\begin{array}{c}\Delta_{a} \\
(\mathrm{~mm})\end{array}$ & $\begin{array}{c}\text { Cek setelah } \\
\text { diperkuat }\end{array}$ \\
\hline Lt 3 & $3,86 \%$ & $1,80 \%$ & $2,5 \%$ & OKE \\
Lt 2 & $2,16 \%$ & $1,06 \%$ & $2,5 \%$ & OKE \\
Lt 1 & $0,00 \%$ & $0,00 \%$ & $2,5 \%$ & OKE \\
\hline
\end{tabular}

Berdasarkan hasil analisis numerik tersebut, setelah struktur diberi perkuatan global (bracing baja) terdapat $31 \%$ kolom dan $32 \%$ balok perlu diperkuat dengan menggunakan metode wrapping dengan CFRP. Penentuan jumlah lapis $C F R P$ yang diperlukan dihitung berdasarkan standar yang berlaku yaitu, SNI 2019 dan ACI 440.2R-08 [11].

Hitungan perkuatan kolom dilakukan dengan hitungan manual berdasarkan standar yang berlaku. Berikut adalah langkah perhitungan perkuatan pada kolom. Perilaku FRP wrapped pada beton dengan mencantumkan perhitungan analitis menggunakan model dari peneliti lain [10]. 
Berikut adalah formula untuk menghitung kuat tekan beton yang disarankan oleh ACI Committee 440 [12].

$$
\begin{aligned}
& \quad f^{\prime} c c=f^{\prime} c\left[2,25 \sqrt{1+7,9 f_{1} / f^{\prime}{ }_{c}}-2 f_{1} / f^{\prime}{ }_{c}-1,25\right] \\
& f_{1}=k_{a} \rho_{\mathrm{f}} \varepsilon_{\mathrm{fe}} \mathrm{E}_{\mathrm{f}} / 2
\end{aligned}
$$

dengan $\mathrm{f}_{\mathrm{cc}}$ adalah kuat tekan beton yang diperkuat, $\mathrm{f}_{\mathrm{c}}$ adalah kuat tekan beton, $f_{l}$ adalah kuat kekang dari FRP, $\mathrm{r}_{\mathrm{f}}$ adalah rasio perkuatan $F R P, \mathrm{e}_{\mathrm{fe}}$ adalah regangan efektif $\mathrm{FRP}$, dan $\mathrm{K}_{\mathrm{a}}$ adalah faktor pengurangan efisiensi.

Pengaruh peningkatan kekuatan aksial untuk jumlah lapis 1, 3, dan 6 masing-masing adalah 1.29; 2.39; dan 3.04 kali dibandingkan dengan beton yang tidak dililit FRP [10].

Data beton

$$
\begin{aligned}
f_{c}^{\prime} & =12,46 \mathrm{MPa} \text { (lihat Tabel 2) } \\
f^{\prime}{ }_{c c} & =29,78 \mathrm{MPa}(\text { lihat Tabel 2) } \\
E_{c} & =25.648,14 \mathrm{MPa} \\
f_{y} & =396 \mathrm{MPa}(\text { lihat Tabel 3) } \\
E_{s} & =200.000 \mathrm{MPa} \\
\varepsilon^{\prime} & =0,001896 \\
\beta_{l} & =0,84 \\
d^{\prime} & =0 \mathrm{~mm}
\end{aligned}
$$

\section{Data kolom}

$$
b=h=450 \mathrm{~mm}
$$

\section{Data FRP}

$$
\begin{array}{ll}
A_{s} & =0,33 \times 3 \times 450=445,5 \mathrm{~mm}^{2} \\
f_{y} & =3.792 \mathrm{MPa}
\end{array}
$$

Beban pada kolom

$$
\begin{array}{ll}
P_{u} & =1.182,51 \mathrm{kN} \\
M_{u x} & =354,01 \mathrm{kNm} \\
M_{u y} & =113,72 \mathrm{kNm} \\
V_{u} & =49,08 \mathrm{kN}
\end{array}
$$

Kekuatan nominal kolom pada kondisi seimbang

$P_{n b}=435,02 \mathrm{kN}$

$M_{n b}=2.145,88 \mathrm{kNm}$

Posisi nilai c ditampilkan pada Gambar 9 dan diagram interaksi kolom K1.1.1 ditampilkan pada Gambar 10 . Terdapat dua kurva untuk membandingkan peningkatan kapasitas kolom dalam menahan gaya dan momen internal kolom yang terjadi. Kurva warna kuning merupakan kurva interkasi kolom dengan mutu beton eksisting, sedangkan kurva warna biru merupakan kurva interaksi kolom setelah kolom diperkuat dengan 3 lapis FRP. Sehingga diperoleh jumlah lapis yang diperlukan untuk masingmasing elemen kolom yang ditampilkan pada Gambar 11 sampai dengan Gambar 12.

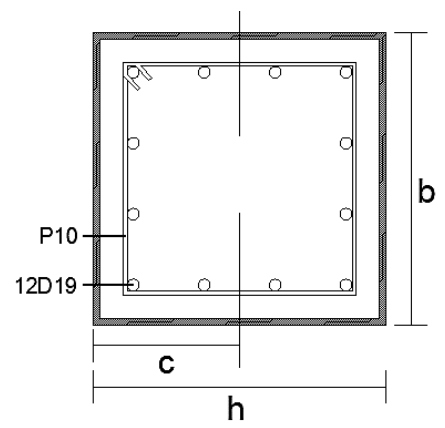

Gambar 9. Penampang dan posisi tulangan kolom

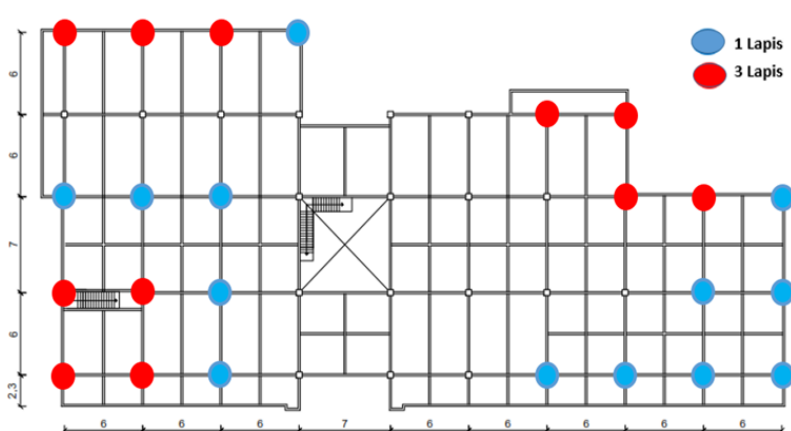

Gambar 11. Jumlah lapis perkuatan $F R P$ kolom lt 1

Elemen balok yang kombinasi kuat geser dengan torsinya tidak memadai, perlu dilakukan perkuatan tulangan geser.

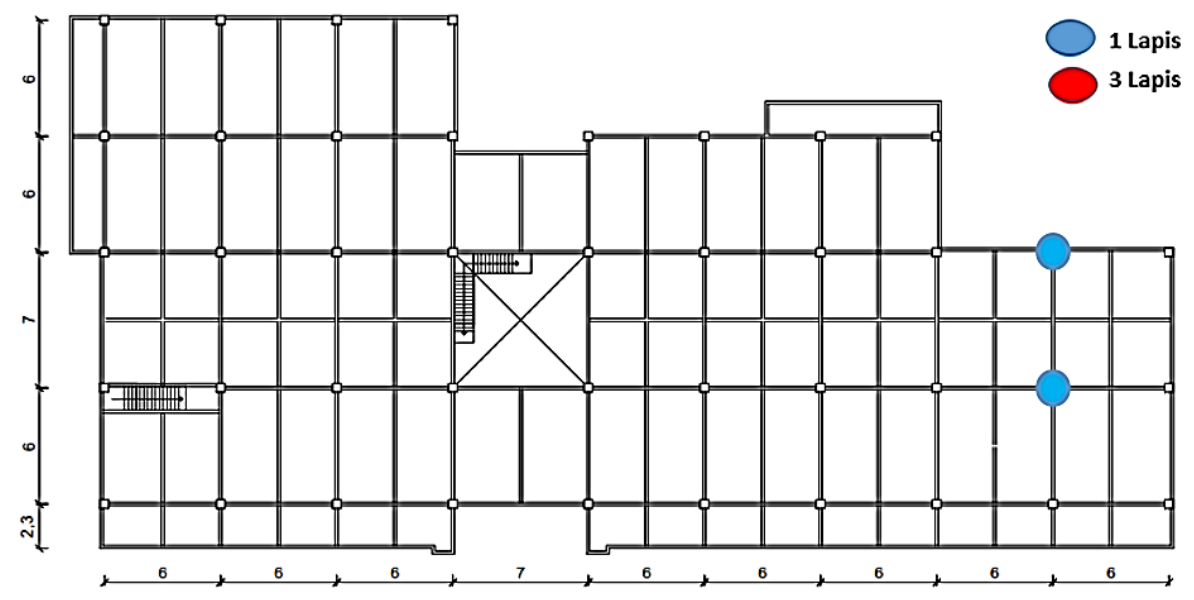

Gambar 12. Jumlah lapis perkuatan $F R P$ kolom lt 2 
Pemeriksaan hasil desain menunjukkan bahwa penulangan geser dari sebagian besar balok di seluruh lantai yang diperlukan lebih besar dibandingkan dengan penulangan geser yang terpasang $\left(\mathrm{mm}^{2} / \mathrm{m}\right)$. Maka perkuatan geser pada pada balok-balok tersebut perlu dilakukan.
Berdasarkan analisis numeris yang telah dilakukan sebelumnya, diperoleh bahwa terdapat 79 balok yang perlu diperkuat dan berdasarkan hasil hitungan berdasarkan standar ACI 440.2R-08 [11]. Berikut adalah langkah perhitungan perkuatan $C F R P$ pada balok.

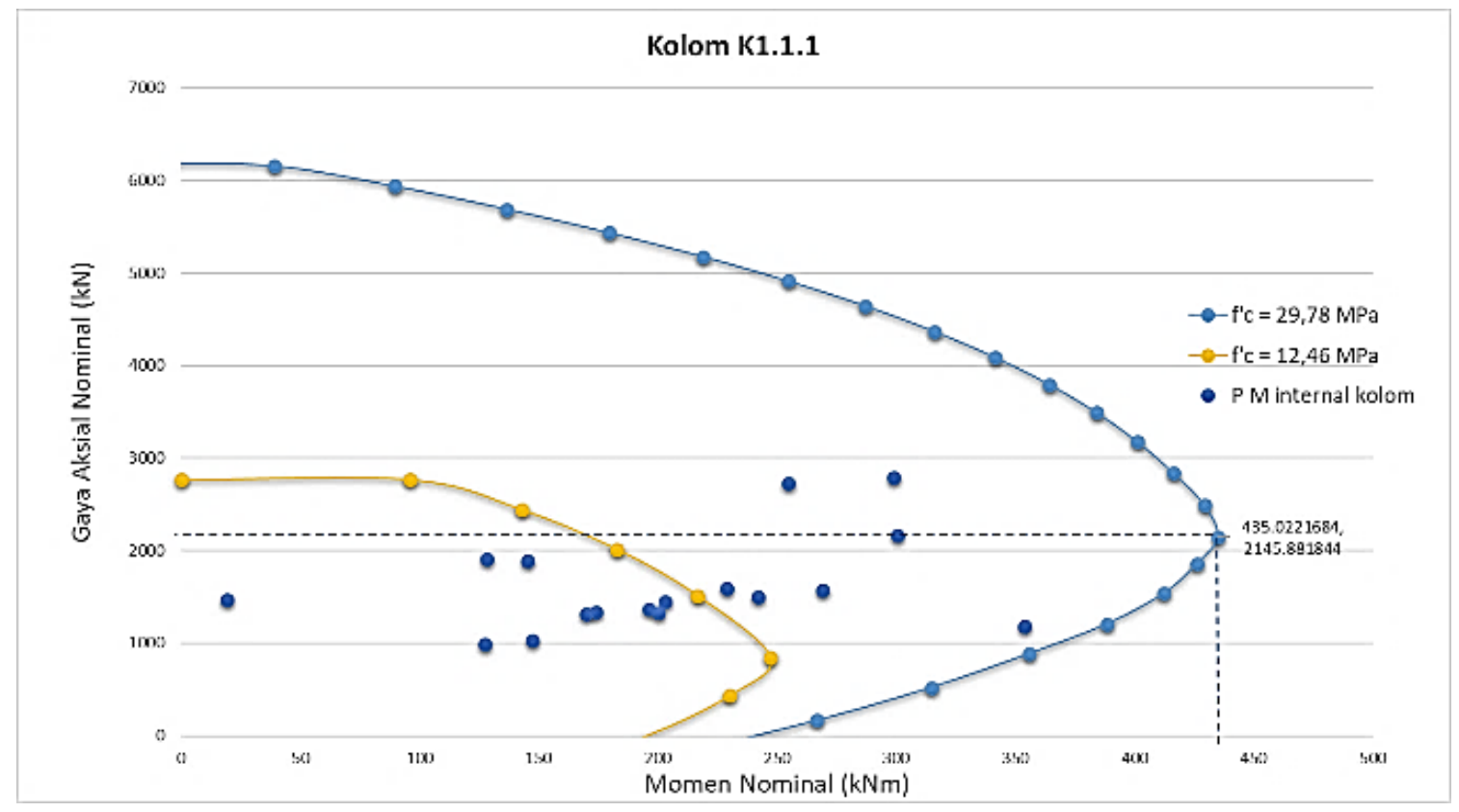

Gambar 10. Diagram interaksi kolom K1.1.1

Perkuatan geser balok

Data balok eksisting

$f_{c}^{\prime} \quad=14,28 \mathrm{MPa}$ (lihat Tabel 5)

$V_{c}=87,009 \mathrm{kN}$

$V_{s} \quad=528,788 \mathrm{kN}$

$f V_{n, \text { existing }}=146,596 \mathrm{kN}$

$V_{u} \quad=f\left(V_{c}+V_{s}\right)=554,217 \mathrm{kN}$

Perkuatan geser CFRP (Penjelasan ditampilkan pada Gambar 13)

$$
\begin{array}{ll}
d & =480-10-9,5=460,5 \mathrm{~mm} \\
d_{f v} & =460,5-120=340,5 \mathrm{~mm} \\
w_{f} & =500 \mathrm{~mm} \\
s_{f} & =500 \mathrm{~mm} \\
L & =5.550 \mathrm{~mm}
\end{array}
$$

(a)

(b)
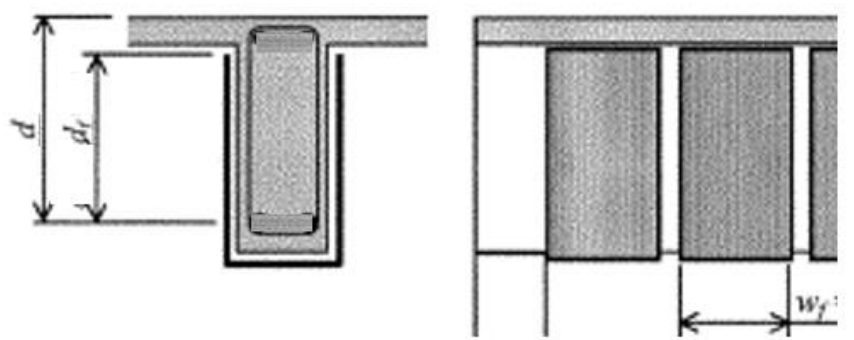

Gambar 13. Potongan melintang dan memanjang perkuatan FRP pada balok

Data balok eksisting

$$
\begin{array}{ll}
\mathrm{t}_{\mathrm{f}} & =0.3 \mathrm{~mm} \\
\mathrm{f}_{\mathrm{fu}} * & =3.500 \mathrm{~N} / \mathrm{mm}^{2} \\
\varepsilon_{\mathrm{fu}} * & =0.015 \mathrm{~mm} / \mathrm{mm}
\end{array}
$$

$$
\begin{array}{ll}
\mathrm{E}_{\mathrm{f}} & =28.500 \mathrm{~N} / \mathrm{mm}^{2} \\
\mathrm{C}_{\mathrm{E}} & =0.9
\end{array}
$$

Menghitung desain material

$$
\mathrm{f}_{\mathrm{fu}}=\mathrm{C}_{\mathrm{E}} \times \mathrm{f}_{\mathrm{fu}} * \quad=3.325 \mathrm{kN} / \mathrm{mm}^{2}
$$


$\varepsilon_{\mathrm{fu}}=\mathrm{C}_{\mathrm{E}} \times \varepsilon_{\mathrm{fu}} * \quad=0.014$

Menghitung regangan efektif pada perkuatan FRP

$\mathrm{n}_{\mathrm{FRP}}=3$ lapis

$\mathrm{L}_{\mathrm{e}} \quad=16,986 \mathrm{~mm}$

$\mathrm{k}_{1} \quad=0.654$

$\mathrm{k}_{2} \quad=0.950$

$\mathrm{k}_{\mathrm{v}} \quad=0.062<0.75(\mathrm{Ok})$

$\varepsilon_{\mathrm{fe}} \quad=\kappa_{\mathrm{v}} \mathrm{X} \varepsilon_{\mathrm{fu}}=0,001<0,004(\mathrm{Ok})$

Menghitung kontribusi perkuatan FRP terhadap kuat geser

$\mathrm{A}_{\mathrm{fv}}=900 \mathrm{~mm}^{2}$

$\mathrm{f}_{\mathrm{fe}}=\varepsilon_{\mathrm{fe}} \times \mathrm{E}_{\mathrm{f}}=0,252775927 \mathrm{~N} / \mathrm{mm}^{2}$

$\mathrm{V}_{\mathrm{f}}=\frac{\mathrm{A}_{\mathrm{fv}} \cdot \mathrm{f}_{\mathrm{fe}} \cdot(\sin \alpha+\cos \alpha) \cdot \mathrm{d}_{\mathrm{fv}}}{\mathrm{s}_{\mathrm{f}}}=154.9 \mathrm{kN}$

Menghitung kuat geser

$\phi \mathrm{V}_{\mathrm{n}} \quad=560,61338 \mathrm{kN}>554,217386(\mathrm{Ok})$

Perkuatan geser balok

Menghitung desain properties FRP

$\mathrm{f}_{\mathrm{fu}} \quad=\mathrm{C}_{\mathrm{E}} \times \mathrm{f}_{\mathrm{fu}} *=3.325 \mathrm{MPa}$

$\mathrm{e}_{\mathrm{fu}} \quad=\mathrm{C}_{\mathrm{E}} \times \mathrm{e}_{\mathrm{fu}} *=0,013$

Hitungan pendahuluan

Ec $\quad=17.760,78 \mathrm{~N} / \mathrm{mm}^{2}$

Asumsi hitungan perkuatan menggunakan 3 lapis FRP

$\mathrm{A}_{\mathrm{f}} \quad=270 \mathrm{~mm}^{2}$

Menghitung regangan

$\mathrm{e}_{\mathrm{bi}} \quad=0,00017$

Menentukan regangan desain FRP

$\mathrm{e}_{\mathrm{fd}}=0,0097 \leq 0,0115$

$\mathrm{e}_{\mathrm{fd}}$ yang digunakan adalah 0,0097

Mengestimasi nilai c (letak garis netral)

a $\quad=94,603 \mathrm{~mm}$

c $\quad=a / b=111,29 \mathrm{~mm}$

Menentukan tingkat efektivitas regangan pada FRP $\mathrm{e}_{\mathrm{fe}} \quad=0,0098 \geq 0,0097$

$\mathrm{e}_{\text {fe }}$ yang digunakan adalah 0,0097

$\mathrm{e}_{\mathrm{ce}}=0,00297$

Menghitung regangan tulangan eksisting

$\mathrm{e}_{\mathrm{s}} \quad=0,0094$

Menghitung stress pada tulangan dan FRP

$\mathrm{f}_{\mathrm{s}} \quad=\mathrm{E}_{\mathrm{s}} \mathrm{x} \mathrm{e}_{\mathrm{s}} \leq \mathrm{f}_{\mathrm{y}}=1,87 \geq 0,405$

$\mathrm{f}_{\mathrm{s}}$ yang digunakan adalah 0,405

$\mathrm{f}_{\mathrm{fe}} \quad=\mathrm{E}_{\mathrm{f}} \times \mathrm{e}_{\mathrm{fe}}=0,276$

Menghitung resultan tekanan internal dan keseimbangan

$\mathrm{b}_{1} \quad=1,106$

$\mathrm{a}_{1} \quad=0,541$

$\mathrm{e}_{\mathrm{c}}=0,0014$

c $\quad=163,489 \mathrm{~mm}$

Menghitung ulang letak garis netral

Dilakukan iterasi dengan nilai $c$ berbeda sampai keseimbangan tercapai. Hasil akhir dari iterasi tersebut adalah:

$c=149.656 \mathrm{~mm} ; e_{s}=0.006 ; \mathrm{f}_{\mathrm{s}}=405 \mathrm{MPa} ; \mathrm{b}_{1}=1.079 ; \mathrm{a}_{1}$ $=0.569 ; \mathrm{f}_{\mathrm{fd}}=0.184 \mathrm{MPa}$.

Menghitung kuat lentur komponen

$\mathrm{M}_{\mathrm{ns}} \quad=130.812 \mathrm{kNm}$

$\mathrm{M}_{\mathrm{nf}} \quad=19.808 \mathrm{kNm}$

Menghitung desain kuat lentur setelah diperkuat

$\mathrm{fM}_{\mathrm{n}} \quad=134.567 \mathrm{kNm}$

$\mathrm{M}_{\mathrm{n}} \quad=168.209 \mathrm{kNm}>\mathrm{M}_{\mathrm{u}}=151.96 \mathrm{kNm}(\mathrm{Ok})$

Sehingga jumlah lapis FRP yang diperlukan untuk mendukung kuat lentur dan kuat geser balok adalah 3 lapis FRP.

Perhitungan bahan dan upah didapat dari koefisien satuan yang mengacu pada SNI 7393:2008 [13] bagian LA.12 yang dibutuhkan dikalikan dengan harga satuan pada masing-masing pekerjaan. Harga satuan bahan dan upah didapat dari data daerah DKI Jakarta.

Tabel 10. AHS pekerjaan pemasangan $1 \mathrm{~kg}$ baja IWF

\begin{tabular}{|c|c|c|c|c|c|}
\hline No & Uraian & Koef. & Satuan & Harga Satuan (Rp) & Total Harga (Rp) \\
\hline \multirow[t]{5}{*}{ A } & Tenaga Kerja & & & & \\
\hline & Pekerja & $\mathrm{OH}$ & 0.06 & $99.000,00$ & $5.940,00$ \\
\hline & Tukang las & $\mathrm{OH}$ & 0.06 & $130.000,00$ & $7.800,00$ \\
\hline & Kepala tukang & $\mathrm{OH}$ & 0.006 & $145.000,00$ & 870,00 \\
\hline & & & Jumlah & & $14.610,00$ \\
\hline \multirow[t]{6}{*}{$\mathrm{B}$} & Bahan & & & & \\
\hline & Baja IWF & $\mathrm{kg}$ & 1.15 & $14.980,00$ & $17.277,00$ \\
\hline & & & Jumlah & & $17.277,00$ \\
\hline & & & Total Harga & & $18.097,00$ \\
\hline & & & PPN & & $1.809,70$ \\
\hline & & & Sub Total & & $19.906,70$ \\
\hline
\end{tabular}


Tabel 11. AHS pekerjaan pengecatan $1 \mathrm{~m}^{2}$ permukaan baja IWF

\begin{tabular}{|c|c|c|c|c|c|}
\hline No & Uraian & Koef. & Satuan & $\begin{array}{l}\text { Harga Satuan } \\
\text { (Rp) }\end{array}$ & Total Harga (Rp) \\
\hline \multirow[t]{4}{*}{$\mathrm{A}$} & Tenaga Kerja & & & & \\
\hline & Tukang cat & $\mathrm{OH}$ & 0.2 & $130.000,00$ & $7.800,00$ \\
\hline & $\begin{array}{l}\text { Kepala } \\
\text { tukang }\end{array}$ & $\mathrm{OH}$ & 0.012 & $145.000,00$ & $1.740,00$ \\
\hline & \multicolumn{4}{|c|}{ Jumlah } & $15.480,00$ \\
\hline \multirow[t]{9}{*}{ B } & Bahan & & & & \\
\hline & Menie besi & $\mathrm{kg}$ & 0.1 & $45.384,62$ & $4.538,46$ \\
\hline & Cat & $\mathrm{kg}$ & 0.3 & $60.000,00$ & $18.000,00$ \\
\hline & Pengencer & $\mathrm{Kg}$ & 0.01 & $30.000,00$ & 300,00 \\
\hline & Kuas & Buah & 0.01 & $11.283,96$ & 112,84 \\
\hline & \multicolumn{4}{|c|}{ Jumlah } & $22.951,30$ \\
\hline & \multicolumn{4}{|c|}{ Total Harga } & $51.851,30$ \\
\hline & \multicolumn{4}{|c|}{ PPN } & $5.185,13$ \\
\hline & \multicolumn{4}{|c|}{ Sub Total } & $57.036,43$ \\
\hline
\end{tabular}

Tabel 12. RAB perkuatan bracing baja

\begin{tabular}{clcccr}
\hline No & \multicolumn{1}{c}{ Uraian } & Satuan & Luasan & Harga Satuan (Rp) & Total Harga (Rp) \\
\hline 1 & Pekerjaan pemasangan bracing & $\mathrm{kg}$ & 634.7 & $19.906,70$ & $126.243 .513,79$ \\
2 & Pekerjaan pengecatan & $\mathrm{m}^{2}$ & 215.1 & $57.036,43$ & $11.698 .947,74$ \\
3 & Pekerjaan pemasangan angkur & buah & 384 & $300.000,00$ & $115.200 .000,00$ \\
\hline \multicolumn{5}{c}{ Total } \\
\hline
\end{tabular}

Tabel 13. AHS 1 lapis CFRP (Fosroc)

\begin{tabular}{lllllr}
\hline No & Komponen & Satuan & Quantity & $\begin{array}{l}\text { Harga } \\
(\mathrm{Rp})\end{array}$ & dasar \\
\hline 1 & Carbon fiber fosroc & $\mathrm{m}^{2}$ & 1 & $1.650 .000,00$ & Sub total (Rp) \\
2 & Plesteran tebal $15 \mathrm{~mm}$ & $\mathrm{~m}^{2}$ & 1 & $125.000,00$ & $1.650 .000,00$ \\
3 & Alat bantu mobilisasi & $1 \mathrm{~s}$ & 0.002 & $15.000 .000,00$ & $125.000,00$ \\
& Sub Jumlah Bahan & & & & $33.211,26$ \\
& Profit and overhead (10\%) & & & & $1.808 .211,26$ \\
& Total harga satuan & & & & $1.909 .469 .637,48$ \\
\hline
\end{tabular}

Tabel 14. AHS 3 lapis CFRP (Fosroc)

\begin{tabular}{|c|c|c|c|c|c|}
\hline No & Komponen & Satuan & Quantity & Harga Dasar (Rp) & Sub Total (Rp) \\
\hline & Bahan, upah, dan alat & & & & \\
\hline 1 & Carbon fiber fosroc & $\mathrm{m}^{2}$ & 3 & $1.650 .000,00$ & $4.950 .000,00$ \\
\hline 2 & Plesteran tebal $15 \mathrm{~mm}$ & $\mathrm{~m}^{2}$ & 1 & $125.000,00$ & $125.000,00$ \\
\hline \multirow[t]{4}{*}{3} & Alat bantu mobilisasi & Ls & 0,002 & $15.000 .000,00$ & $33.211,26$ \\
\hline & Sub Jumlah Bahan & & & & $5.108 .211,26$ \\
\hline & Provit dan Overhead (10\%) & & & & $510.821,13$ \\
\hline & Total Harga Satuan & & & & $5.619 .032,39$ \\
\hline
\end{tabular}

Perkuatan CFRP yang digunakan sebagai perkuatan dalam kasus ini adalah merk Fosroc dengan rincian perhitungan harga sebagai berikut. Biaya total perkuatan ditampilkan pada Tabel 15.

Tabel 15. RAB total pekerjaan perkuatan

\begin{tabular}{clr}
\hline No & \multicolumn{1}{c}{ Pekerjaan } & Total Harga (Rp.) \\
\hline 1 & Perkuatan Bracing Baja & $253.141 .659,46$ \\
2 & Perkuatan Kolom & $610.733 .640,00$ \\
3 & Perkuatan Balok & $1.045 .594 .338,02$ \\
\hline & total & $1.909 .469 .637,48$ \\
\hline
\end{tabular}

Perhitungan biaya pembangunan gedung kantor PT. PLN Tanjung Priok didasarkan pada Standar Harga Satuan Tertinggi Bangunan Gedung Nasional (HST-BGN). Standar HST adalah biaya paling banyak per meter persegi pelaksanaan konstruksi pekerjaan standar untuk pembangunan bangunan gedung negara [14]. Berdasarkan situs resmi Kementerian Perencanaan Pembangunan Nasional/Badan Perencanaan Pembangunan Nasional (Bappenas), pedoman harga satuan per $\mathrm{m}^{2}$ tertinggi Bangunan Gedung Negara (BGN) tahun anggaran 1998/1999 untuk DKI Jakarta adalah Rp 1.256.000 per m² 
untuk bangunan gedung B (gedung kantor). Nilai HST tersebut dikonversi ke tahun rencana pembangunan gedung, yaitu 2021 dengan menggunakan persamaan future value.

$\mathrm{FV}_{2021}=\mathrm{PV}_{1998} \mathrm{x}(1+\mathrm{r})^{\mathrm{t}}$

Berdasarkan Persamaan 3, diperoleh bahwa nilai Harga Satuan Tertinggi Bangunan Gedung Negara untuk gedung kantor tahun 2021 adalah Rp. 2.913.920 per $\mathrm{m}^{2}$. Adapun luasan bangunan gedung kantor PT. PLN Tanjung Priok adalah $3.536 \mathrm{~m}^{2}$, maka taksiran biaya pembangunan gedung kantor PT. PLN adalah Rp. 11.000.193.369,64.

Biaya taksiran tersebut dikurangi dengan nilai susut bangunan. Bangunan gedung kantor PT. PLN Tanjung Priok ini dibangun pada tahun 1982. Jika gedung tersebut akan dibangun pada tahun 2021, maka umur bangunan tersebut menjadi 39 tahun. Nilai susut bangunan per tahunnya adalah $2 \%$. Sehingga nilai bangunan setelah dikurangi nilai susut menjadi Rp. 2.420.042.541,32. Nilai struktur pada umumnya adalah $45 \%$ dari biaya keseluruhan tersebut. Sehingga nilai struktur dari gedung ini adalah Rp. 1.089.019.143,59.

\section{Simpulan}

Struktur yang mengalami kebakaran dengan suhu yang tinggi dapat membuat struktur tersebut mengalami penurunan kekuatan serta kekakuannya dalam menahan beban yang bekerja. Proses analisis dilakukan mulai dari observasi lapangan, pengujian laboratorium hingga analisis struktur. diperoleh bahwa struktur gedung tidak memenuhi persyaratan dalam kekuatan dan kekakuan. Hal tersebut dapat dilihat salah satunya dari kapasitas kolom dan balok yang mengalami overstress.

Pada analisis struktur dalam kasus ini, metode perkuatan yang diberikan adalah perkuatan global (struktur) dan perkuatan lokal (elemen struktur). Perkuatan global yang diberikan berupa bracing baja IWF 200x100x8x5,5 yang diletakkan pada bagian terluar struktur.

Terdapat $31 \%$ kolom dan $32 \%$ balok yang perlu diperkuat. Perkuatan lokal yang diberikan adalah perkuatan CFRP dengan metode wrapping dengan jumlah lapis berbedabeda sesuai hasil hitungan. Setelah struktur diberi perkuatan, drift ratio serta mode shape gedung memenuhi syarat. Elemen struktur yang telah diperkuat juga telah dapat menahan momen dan gaya yang bekerja sesuai dengan standar terbaru yang berlaku.

Biaya perkuatan yang diperlukan adalah $\mathrm{Rp}$. 1.909.469.637,48 ditambah dengan biaya struktur gedung setelah disusut, yaitu Rp. 1.089.019.143,59. Total nilai tersebut adalah Rp. 2.998.488.781,07. Nilai tersebut kemudian dibandingkan dengan $45 \%$ nilai struktur gedung, yaitu Rp. 4.950.087.016,34. Sehingga biaya perbaikan masih lebih rendah dibandingkan dengan biaya struktur gedung.

\section{Daftar Rujukan}

[1] H. Priyosulistyo, Sifat-sifat Mekanik Bahan Struktur terhadap Beban Gempa dan Temperatur Tinggi. Yogyakarta: PAU Ilmu Teknik, Universitas Gadjah Mada, 2000.

[2] B. Georgali and P. E. Tsakiridis, "Microstructure of fire-damaged concrete. A case study," Cem. Concr. Compos., vol. 27, no. 2, pp. 255-259, 2005, doi: https://doi.org/10.1016/j.cemconcomp.2004.02.022.

[3] H. Priyosulistyo, B. Suhendro, B. Supriyadi, and Sudarmoko, Analisis Bahan dan Kapasitas Elemen Struktur Beton Pasca Kebakaran. Yogyakarta: Lembaga Penelitian Universitas Gadjah Mada, 2002.

[4] N. R. Short, J. A. Purkiss, and S. E. Guise, "Assessment of fire damaged concrete using colour image analysis," Constr. Build. Mater., vol. 15, no. 1, pp. 9-15, 2001, doi: https://doi.org/10.1016/S0950-0618(00)00065-9.

[5] Badan Standarisasi Nasional, Tata Cara Perencanaan Ketahanan Gempa untuk Struktur Bangunan Gedung dan Nongedung (SNI 1726:2019). 2018

[6] Badan Standarisasi Nasional, Beban Minimum untuk Perancangan Bangunan Gedung dan Struktur Lain (SNI 1727:2018). 2018.

[7] Badan Standarisasi Nasional, Persyaratan Beton Struktural untuk Bangunan Gedung dan Penjelasan (SNI 2847:2019). 2019.

[8] American Society of Civil Engineers, ASCE 41-17: Seismic Evaluation and Retrofit of Existing Buildings. Virginia: American Society of Civil Engineers, 2017.

[9] A. Triwiyono, "Evaluasi kualitas beton dan kekuatan struktur gedung yang telah berdiri pasca kebakaran," 2005.

[10] R. R. Rajappa, "Behavior of FRP Wrapped Concrete Cylinders," West Virginia University, 2004.

[11] ACI Committee 440, "ACI 440.2R-17: Guide for the Design and Construction of Externally Bonded FRP Systems for Strengthening Concrete Structures," American Concrete Institute, USA, 2017.

[12] R. Paretti and A. Nanni, "Axial testing of concrete columns confined with carbon FRP: effect of fiber 
orientation," pp. 1-10, 2002.

[13] Badan Standarisasi Nasional, Tata Cara Perhitungan Harga Satuan Pekerjaan Besi dan Aluminium untuk Konstruksi Bangunan Gedung dan Perumahan (SNI 7393:2008). 2008.
[14] Sumirat, Modul 3: Penyusunan Program dan Pembiayaan Pembangunan Bangunan Gedung Negara. Medan: Ditjen Cipta Karya, Kementerian PUPR, 2017. 